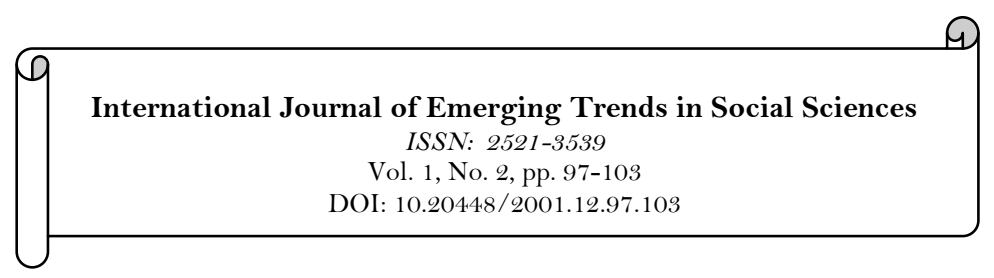

\title{
Building Synergy Strategy “Cawas Lurik Centre” Association to Preserve the Existence of Crafting Business
}

\author{
TheresiaWidiastuti ${ }^{1}$ \\ Nanang Rizali ${ }^{2}$ \\ Sapja Anantanyu ${ }^{3}$ \\ Sugeng Edi Waluyo ${ }^{4}$ \\ ${ }^{1,2,3,4}$ Sebelas Maret University, Indonesia.
}

\begin{tabular}{|c|c|}
\hline Abstract & \\
\hline $\begin{array}{l}\text { Javanese is one of Indonesia's ethnic living in the region of Central Java, } \\
\text { Yogyakarta and East Java. Having three typical types of traditional are } \\
\text { clothing, namely batik, lurik (striated weaving), and jumputan (tye dye). } \\
\text { In Klaten district, Central Java found striated weaving centers, one in } \\
\text { the Cawas district. The main problem faced by the artisans of striated } \\
\text { weaving in this place is likely difficult in marketing products, because } \\
\text { they have to compete the other types of textile markets. As a result, the } \\
\text { craftsman run out of capital, and led to ups and downs state. Therefore, } \\
\text { they work together in a association called the Society of Craftsmen } \\
\text { Cawas Lurik Center. This study aims to determine how the artisans of } \\
\text { striated weaving Cawas seek to be able to continue their efforts. This } \\
\text { research paper uses a form of qualitative research using case study } \\
\text { strategy with phenomenological approach. The results showed (1) the } \\
\text { artisans joined the association as a forum for cooperation between them; } \\
\text { (2) creates synergy among craftsmen to improve the ability and } \\
\text { knowledge, and ( } 3 \text { ) develop synergies with the outside association to } \\
\text { strengthen the group in order to have a bargaining position in the } \\
\text { middle of the competition. }\end{array}$ & $\begin{array}{l}\text { Keywords: } \\
\text { Striated } \\
\text { Association } \\
\text { The Synergy. } \\
\text { Licensed: } \\
\text { This work is licensed under a } \\
\text { Creative Commons Attribution } \\
\text { 4.0 License. } \\
\text { Publisher: } \\
\text { Scientific Publishing Institute }\end{array}$ \\
\hline
\end{tabular}

\section{Introduction}

Striated weaving is a craft that has been made continuously since the first hereditary by Javanese living in Solo, Yogyakarta, and Tuban by using Weaving Hold Equipment (ATG) to meet its own needs, both for everyday use and complement for traditional ceremonies (Djoemena, 2000). Now striated weaving not solely to meet the needs of its own anymore, but to become a livelihood for some residents in some districts in Klaten, which is the area that lies between Solo and Yogyakarta. Many places are available in which people have the skill to make striated weaving. Moreover, almost every family still keeps at least one weaving equipment inherited from parents that can be used, either ATG or Not Weaving Machine Tools (ATBM).

Crafting business becomes potential sector to boost the economy because it provides jobs for local communities and surrounding areas (Schafer, 2007). Including in small business of striated weaving in Cawas. The existence of weaving artisans in Klaten has made a major contribution to the area due to the skills of the craftsmen in producing products known for its simplicity and characteristic of regionalism. In addition, the striping has economic value that possibly to sustain the community as well as to increase region revenue. But as most small businesses are, the striated weaving business also has many drawbacks, one of which is the struggling in marketing. When the striated products accumulate because unsold, then capital will later run out and owners will close down business. Among them there are striated entrepreneurs who bend over backwards to stay afloat even under any circumstances. They seek to find a way out in order to continue their efforts.

The attitude of local government that is less aligned encouraged group consisting of striated artisans and employers to find a way to get out of the problem and to continue striated weaving business. They then agree to join in a association called Cawas Lurik Center (CLC) in January 2014. An association is an organization which is constituted by an inner sense of unity that is already predetermined. According to Endraswara (2016) in any economic activity, Javanese people always associate in harmony and tolerance. Social systems in rural communities that are mutually helpful (gemeinschaft) causes the association formed by Cawas artisan named 'association' which also included into gemeinschaft by blood or blood tie or offspring, who live together in 
same area (Narwoko \& Suyanto, 2013). CLC association was established based on the initiative of seven artisans businessman from Mlese Cabean village, Mlese Gebahan, Tlingsing, Bogor, Burikan, Balak, and Baran; Cawas district.

Through this group, crafters help each other, support, and provide input in dealing with various problems. The condition of small businesses joining in this community is also varying. Some of businesses are more established and some are still always have ups and downs. Cooperation between these craftsmen occurs for two interests consecutively, to proceed with their respective businesses and to complete the consumer's order. Cooperation carried out mainly in the form production sharing, raw material supplying, and marketing. The association is also an open place to learn for improvement of knowledge and skill of the artisan. Learning according to Tabrani (2000) is the appearance of the characteristics of creativity in the visual design planning process which takes place simultaneously in the process of learning, memory and imagination form.

Most members of the community of CLC are mothers. In addition they must take care of the household and help husband fields. Furthermore, as members of society, women cannot be separated from the various things associated with social activities is the local custom. Though they are still required to seek additional income by becoming non-permanent workers in the striated weaving business. Handwork is indeed closely related to women. According Djoemena (2000) since ancient times weaving work has been done by women only. Generally, women in poor and developing countries are the backbone of the family, not only in domestic affairs but also to earn extra income. Their participation in economic activities becomes part of the way towards independence (Ekesionye \& Okolo, 2012; Nachiappan, 2008). The same case also happens in Indonesia.

Association members and administrators establish communication through meetings held regularly to discuss various issues, such as discussing short-term work plan, work division, as well as evaluating the work per month. The communication process is not only to convey information alone, but will continue with the dialogue, so that an exchange of information, ideas, and various other inputs (Mardikanto, 2010). Besides the regular meeting of the community often invite experts to give input of knowledge and skills. Sometimes these experts come on its own initiative to provide training on new things related to weaving problems. Group study while working formed by the craftsman begins with the same expectations that wants to earn revenue from the products, and striated weaving business can keep running. According to Brundage and Mackerarcher learning for adults is a process initiated by individuals when seeking change or enrichment for their knowledge, values, skills, strategies and behavior of every individual. The behavior of adults in learning is the result of learning experiences in the past, while the current study results will determine the performance and conditions in the future (Basleman \& Mappa, 2011).

The members of the association also work to complete the order coming into their own businesses. In the primary group of individual persons tend to prefer working in a team as a member rather than working alone as an individual (Narwoko \& Suyanto, 2013). This partnership has been running before the community stand. Generally, the craftsman entrepreneurs share time to harness the labor craftsmen whom mostly are temporary workers. Once together, within a period of approximately six months members of the association can feel the results of the sale of a striated better way than before. The products they make begin to be sold not only in the region Cawas, but also to the outside Klaten across provincial borders. This is partly due to partners who have established a working relationship with the founders of the community since before the association was formed. These conditions encourage each member to continue to produce weaving striated be accepted by society.

\section{Methodology}

Observation was generally conducted to activities of the craftsmen who are members of the community striated in particular and striated artisans in Cawas. This study sought to understand the meaning of events and human interaction in a special situation (Sutopo, 2002) namely the significance of the ideas and actions of the craftsmen who joined the association of Cawas Lurik Center artisan in empowering their own initiative. The research data was collected through interviews with the weaving striated artisans, whether integrated or not to join the Society of CLC, Government through the Department of Industry, Trade Cooperatives and UMKM Klaten, Department of Tourism Culture Youth and Sports Klaten, village leaders, CLC community partners, designers, academics; for further inductive process as an effort to build a complete picture.

Based on the problems studied, then this research is a case study with a phenomenological approach. Using data triangulation technique, in which the two data from different sources can be compared to see whether it is trusted or otherwise. According Moleong (2014) qualitative approach is used to social problems to find a new perspective on certain problem that is already widely known in advance. Characteristics of qualitative research include the natural setting. Furthermore documenting setting, activity of striated artisans in Cawas district, and analyzing of documents and monographs of striated weaving craft center in Cawas.

\section{Association as Cooperation Media}

Based on the findings of this research, it is known that there are some periods that illustrate the striated weaving business conditions in Klaten, one of them is the period after the May 2006 earthquake hit parts of 
Klaten and caused the destruction of both public facilities and homes; including most of the existing weaving equipment. In order to rehabilitate the post-earthquake conditions striated artisans, many local governments got a hand from many outside parties, such as the Non-Governmental Organization (NGO) in Indonesia and abroad. One of these NGO Gita Pertiwi Surakarta was financially helped by 'Australian Indonesia Partnership'. They strive to empower the artisans back in Klaten including craftsmen from Cawas. NGO is community groups formed voluntarily and not profit-oriented, organized in local, national, or international. Oriented task to run a variety of services and humanitarian functions, bring the concerns of the community to the government, monitor policies and encourage participation in political community level (Todaro \& Smith, 2006).

Recovery program focuses on the improvement of production facilities, the provision of venture capital, and group empowerment program conducted in five villages in the Cawas; Japanan, of Pakisan, Balak, Baran, and Tirtomarto. It turned out that these activities provide some positive impacts, so many craftsmen from other villages such as Bogor, Tlingsing, and Mlese interested in assisting developing skills for their respective business purposes. Post-rehabilitation striated weaving business conditions have not run as expected because most striated artisans in Cawas is still having trouble marketing. Even many who choose to close down company because it ran out of capital. But there are artisans who continue to work in ways to make their products are totally sold, so that their business can still continue to exist.

Viewing from the level of independence of artisan, there are two groups of Cawas striated artisan, a group of independent artisans who own and run the business, and a group of artisans who tend to be submissive and prefer to rely on other parties in order to remain in existence. The second group is more numerous than the first group. Nevertheless the two aforementioned groups coexist harmoniously like life in the countryside. They help each other help in all matters including those related to their work as striated artisan.

Post-rehabilitation centers that do striated weaving with funding and assistance from NGOs, local government of Klaten district set eleven typical cluster featured business types Klaten, one cluster striated. Expectation of artisans is through this cluster they can channel their aspirations, as well as get the solution of various problems that have persisted. But after a cluster is formed, the artisans actually do not feel any changes because the cluster activity does not go as planned previously. The main problems such as difficulties in obtaining raw materials and marketing is still unsolved. These conditions then encourage the artisans have agreed to work in synergy. At the beginning of the formation of the community, the number of members were 26 artisans. In the past two years later the number of members went up to 88 people artisan.

The concept of synergy according to Cattell in Sulasmi (2009) describes the behavior of the group formed by the interaction of its members. Synergies become the basis for the realization of productive quality in the form of the achievement of a common goal. At least in the synergy required skills and knowledge complementarity among individuals in the group, there is a willingness to work together for mutual benefit, there is mutual trust and openness, and there are the same rights. Synergy means collaboration among individuals who have the same goal, so that the working group later be strong. The problem often faced by every business in Cawas striated weaving around the issue of lack of capital, raw materials, and difficulty in marketing their products. Therefore, through the community of artisans cooperation in the form of supply of raw materials, production processes, and marketing. In addition they are also jointly working to improve the potential of existing human resources, improvement of product quality, marketing and regional development through various activities.

Prior to forming the association, the founders have a working relationship with various parties, such as NGOs, academics, fashion designers, private, non-profit organization associated with the textile, and the public who have an interest and concern for traditional, including weaving striated artisan or consumer; in addition to the local government. They all have their own roles that directly or indirectly support the sustainability of striated weaving business, through activities that can improve the ability of the craftsman, the development of textile products quality and aesthetics, promotion to marketing. The presence of good relationships will open more opportunities. Good relationships with stakeholders can be continued until present time. In this partnership there is a mutually beneficial relationship for both parties, namely the CLC association and stakeholders. Through this relationship is expected Cawas striated weaving into a much broader market than before. Besides the input received by association allows members of the association to improve their knowledge and abilities.

According Soetomo (2012) association as part of a social group is a form of coexistence in which the members are bound by the inner relationship, purely natural and eternal. This is because the community can mainly be found in the family, group and neighborhood. In the community there is a shared willingness, an understanding, as well as the rules that arise naturally within the group. According Garna (1996) there are three types of community, associaton because of blood ties (gemeinschaft by blood), association as a place (gemeinschaft of place), and community as a soul-mind (gemeinschaft of mind).

Based on the type then the Cawas Lurik Center artisan includes the community as a place (gemeinschaft of place), consists of people who are near the residence, so they can be very helpful to each other, like the neighborhood. They have the same thoughts about the importance of maintaining and developing the craft of striated weaving effort that has been done for generations. Seeing the activities carried out by artisans in the 
community regarding to economic issues, the group striated Cawas artisans can also be referred to patembayan, namely social group whose members have a bond of birth principal for a short period (Soekanto, 2012). Forming of activity and an increasing of artisans weaving CLC community members showed mixed form between the community and patembayan.

But the CLC community is still an informal organization whose membership is still flexible, because not all members are aware of the importance of this cooperation, and also takes vision, mission and strict rules. In other words if the community wants to have a high bargaining power of the market, it must first be organized. To achieve independence as expected, the community of CLC is not only to increase the capacity of resources, effort, and the environment, but also to improve its institutional capacity.

\section{Work Description to Achieve Target}

Together with members of the association board of Cawas Lurik Center artisans to arrange coordination of work that concentrates on the development and innovation, procurement of materials and production, partnerships and public relations, and marketing and promotion. In addition, members of the association participated in formulating community action programs including work planning and tasks description that are tailored to the skills / abilities of each individual. According to Sopiah (2008) work team generates positive synergies through a coordinated effort. A good number of group members tend to be small, or no more than twelve persons. Thus it is easier to interact, in which each member has a reciprocal commitment and responsibility in order to achieve high performance. The main purpose of the program of activities which they set is for striated weaving business to continue and grow. Work is primarily focused on the production and marketing process striated.

The production process includes planning, technical execution, finishing or completion of the product, up to the application of products tailored to the needs of consumers while marketing includes planning, execution through creative efforts in the form of promotional activities, distribution, sales, and evaluation. Both the production and marketing process mentioned above is a design process. It is huge concern for participants to be highly creative in order to continue the striated weaving products as handicraft products as legacy the can be continued. According Torang (2016) performance is the quantity and or quality of the work of an individual or group of people in performing basic tasks and functions irregularly in the norm, standard operating procedures, criteria, and measures that have been established or accepted.

Based on the source of the legend in some regions of the archipelago is described that job from the beginning of weaving done by women and is an honor for women whom are good at weaving, because these skills can improve women's dignity (Djoemena, 2000). Striated weaving has been done in continuity by women in Cawas, and hereditary until now. Therefore, in the data of Department of Industry, Trade and Cooperation Klaten number of striated artisans categorized as numerous. All striated weaving business in Cawas is household enterprises conducted by one family. On the other side, working with own family means not having to incur the cost of paying labor. On the other hand with the limited manpower in addition to causing the production process is often limited, so the striated weaving business could not develop because of the amount of production is few.

Seeing from role in the weaving process, the ratio of entrepreneur artisans, sekir (grinder) craftsmen and labor craftsmen are very unbalanced. Currently most of the largest labor is craftsmen, and the least is grinder artisans. It is a major need especially on grinder who is able to make designs and also do grinding. Grinders have an important role in the process of making striated, because he was in charge of making the main pattern. This work is not only enough just shaped by habit and skill, but also requires knowledge of its own. Grinding requires concentration and accuracy.

Striated weaving business in the village Mlese, Balak, Baran, Burikan, Japanan, of Pakisan, Cawas, in average has two up to ten artisans. The striated weaving business generally divides division of labor, but is unwritten. Therefore it is still going on their working odd jobs, especially at the time of booking, and there are many crafters workers who are absence, so worker must handle several jobs at once. Therefore, for the implementation of production usually business owners still have to be ready to participate in completing the work. Often this is because the owner also has the burden of working, consequently become less focused on surveillance which ultimately affects the quality of the product.

\section{Insights to Develop Design}

Striated is a traditional product with a simple appearance, but the manufacturing process was not as simple as its appearance. Its uniqueness lies in the texture of the fabric and the density of the yarn is not exactly the same, so it looks natural. Striated is the name fabric, striated word itself comes from the Javanese language, which means stripes patterns, which is the epitome of simplicity. Simple in appearance, elaborate in manufacture, and full of meaning (Djoemena, 2000). In addition to functioning to seal and protect the body, striated also has a function as a status symbol and a Javanese ritual function to mark each part of the cycle of human life. In Yogyakarta, striated used as a soldiers uniform Karaton Yogyakarta Sultanate since past until now. 
All equipment weaving is a simple tool made of wood strung simple, sometimes even given a booster stone or brick that can be operated manually because of the entirely using manpower as a vehicle. In practice making weaving cloth is not as simple shape tools. This must go through a fairly complicated process. For crafters who've been doing it a long time, it becomes a habit that makes them highly skilled. It takes patience and thoroughness itself up into a beautiful piece of cloth. If the first job of women to weave, now is also carried out by men for a living. Traditional handicrafts can be one of the industrial sectors that are able to contribute to economic growth (Buthani, 2013).

The most important part of weaving the striated is grinding, which is the process of determining a pattern on a weaving yarn striated by arranging one by one according to the desired color. Grinder must have the expertise to organize the warp threads to be parallel to each other to the width of the fabric and structure of the desired color to form a pattern on the striated fabric. Besides must have the knowledge, skills, is also able to be creative to make a variety of alternatives in a striated pattern. In addition, supposedly able to read or understand the design drawings created by others. The number of grinding workers in Cawas is few in number little. Almost all grinders are generally women whom are housewives.

In an effort to craft there are always problems to be solved in the framework of the implementation of the design process. These problems include whether or not the products are used, if it can be produced, marketed, and whether the product has appeal to attract consumers. It is necessary to solve creative effort so that the products can be sold. The design process is a creative activity that aims to meet human needs utilizing the technology by taking into account of several important factors, such as human factors, economic, time, rules, and creativity arising from their interaction with the surrounding environment; in order to achieve maximum results (Sachari, 2005). The production on small business activities including weaving striated Cawas, changing yarn material into a weaving fabric that is ready for market. This activity requires skilled resources, raw materials, and equipment.

Crafters willingness to continue learning and mastering various working parts mainly for weaving is considered as the most difficult part, namely grinding; is a positive step that will not only benefit the individual as a craftsman who work on but also for the group. The craftsmen have not thought of to make skeletal-related functions, such as for example of the user: age, status, gender, and so on. From the aesthetic aspects of craftsmen in making striated only based on the number of alternative colors and arrangement of lines and not to take into consideration of the idea of an alternative theme of striated pattern to produce an attractive option in order to avoid monotony. Similarly, in the aspect of the process, artisans have not the capability of the power production and repetition. Another thing entirely untouched is the fashion aspect to consider fashion trends to suit the needs of potential users. Similarly, the aesthetic requirements are tailored to market demand or buyer.

Weaving striated made during this time is for clothing materials, long cloth or jarit, gloves, stagen, scarves. In making striated craftsmen still consider aspects that exist in the circuit design process, which is a function, aesthetics, materials, processes, and fashion. So far they are working on a new style based on customer demand.

Most products are made of striated weaving Cawas craftsmen are fabrics for clothing materials. Even if has been applied into ready-made garments, the model is made is not directed at the market certain. The target market is a group of consumers who are specifically targeted marketing efforts, involving vulnerable groups of consumers regarding to socio-economic factors. Included in the target market is the market share, relating to the buyer age factor, education, lifestyle, and so on Rizali (2012). The craftsmen did not know about the design process. What has been created just a habit that has been done, thus making often considered as spontaneous.

The presence of outsiders who want to help the craftsmen also be especially beneficial. Outside parties include non-profit institutions sort of Cita Weaving Indonesia (CTI), the fashion designer who came from Yogyakarta, Bandung and Jakarta, the academics of Textile Craft Faculty of Art and Design program Institute of Technology Bandung, the study program Textile Craft School University of Art and Design March Surakarta, Textile Department of the Indonesian Islamic University in Yogyakarta, Trisakti University Bina Nusantara University ,; and courses related to management issues such as the Faculty of Economics, Sebelas Marert University; to provide a wide range of input on the development of design and business management issues.

Outside assistance beyond manifested in various forms of activities that aim to provide insight and training related to the problem of materials, colors and techniques. The result is expected to improve the quality and aesthetic products. The presence of academics and designers to craftsmen middle striated in Cawas bring back natural dyes to be used as a dye of striated. Similarly, consumers from abroad, such as Japan, for example, ordered striated with artificial coloring, thus enriching the alternate color on striated Cawas later is important. In the implementation of community development, the basic principles of community assistance under (Soetomo, 2012) among others, is the process of learning, sharing, and mutually reinforcing. Development and self- improvement principally directed to improve the quality of which is indispensable in order to improve business productivity. 
The empowerment program orientation process where in each stage has an element of learning to manage a program, learning management jobs involving public participation as the perpetrator of the program. It could be said merely easy because it is in the process, an empowerment program has prioritized important issues but also generate an understanding of the values of a broader philosophical. In the context of empowering themselves and give priority to our relationship with humans, the way people interact with each other and their relationship to accept and implement to run program.

\section{Conclusion}

The importance of a partnership in social life is to be able to do a lot of things into a common need. By working together to do the division of tasks that can be completed quickly. One function of the dynamics of the group is to increase democratic society, individuals from one another can provide feedback or interact with each other and have the same role. In the research and society discussion can be concluded:

Efforts to work together in the form of a group is the best way to solve the same problem for every crafter striated weaving. In this case the artisans form associations as a media for cooperation. In principle every crafter already has its own potential to contribute in work group. The division of tasks is very beneficial for the production process they are doing.

At least every household has a business that hopefully can keep running, while the jobs that have been shared within the group can be realized well. Benefits for the craftsmen striated group is a venue to discuss, share and learn, and as a source of information for various things, especially relating to the concerned business, one of which market information.

Through group as a member of the crafters also can expand the cooperation network with those outside groups directly or indirectly next will have a positive outcome for the striated business. Various inputs associated with the design process regards including the planning to the production process and marketing process including planning, execution through creative efforts in the form of promotional activities, distribution, sales, and evaluation; which have not performed by small entrepreneurs weaving striated, through a group generally can be studied. A new insights that are not easy to understand if it is not implemented, so the artisans as a member of the group can learn in the implementation of ongoing production.

\section{References}

Basleman, A., \& Mappa, S. (2011). Adult learning theory. Bandung: PT Remaja Rosdakarya Publisher.

Buthani, P. M. M. (2013). Handloom Indians: Boom to the Nation in Jeopardy. The International Journal of Business and Management.

Djoemena, N. (2000). Lurik. Fruit lines. Jakarta: Djambat Publisher.

Ekesionye, E. N., \& Okolo, A. N. (2012). Women empowerment and participation in economic activities: Indispensable tools for self-reliance and development of Nigerian society. Educational Research and Reviews, 7(1), 10-18.

Endraswara, S. (2016). Javanese living philosophy. Exploring the pearls of policy from the essence of Kejawen philosophy. Yogyakarta: Horizon Publishers.

Garna, J. K. (1996). Basic social sciences-concept-position. Bandung: Postgraduate Program at Padjadjaran University.

Mardikanto. (2010). Communication development. Reference for academics, practitioners and development communication enthusiasts. Surakarta: Eleven March University Press.

Moleong, L. (2014). Qualitative research methodology. Bandung: PT Remaja Rosdakarya Publisher.

Nachiappan. (2008). The economic enforcement of women: The case of working women's forum. Journal of International Women's Studies.

Narwoko, J. D., \& Suyanto, B. (2013). Sociology of introduction and applied texts. Jakarta: Kencana Prenada Media Group.

Rizali, N. (2012). Textile design method. Surakarta: UNS Press.

Sachari, A. (2005). Introduction to the visual culture research methodology: Design, architecture, fine art and craft. Jakarta: Erlangga Publisher.

Schafer. (2007). Small business survival and inheritance: Evidence from Germany. Small Business Economic Journal.

Soekanto, S. (2012). Introduction to sociology. Jakarta: Rajawali Press.

Soetomo. (2012). Community self-reliance. Yogyakarta: Student Library.

Sopiah. (2008). Organizational behavior. Yogyakarta: Andi Publisher.

Sulasmi, S. (2009). The role of innovative learning behavior variables, intensity of group collaboration, togetherness of vision and mutual trust in forming quality synergy. Surabaya: Equity of Airlangga University.

Sutopo, H. (2002). Qualitative research methodology: Basic theory and applied in research. Surakarta: Eleven March University Press.

Tabrani, P. (2000). Process of creation, appreciation, learning. Bandung: ITB Publisher.

Todaro, P., \& Smith, S. (2006). Economic development (Issue 9). Jakarta: Erlangga Publisher.

Torang, S. (2016). Organization and management (Behavior, Structure, Culture and Organizational Change). Bandung: Alfabeta Publisher. 


\section{Bibliography}

Goldsmith, J. (2012). Sustaining rural life and work through textile handwork: Before and after industryalization. Proceedings of the Eighth International Conference on Environmental, Cultural, Economic, and Social Sustainability, Vancouver.

Hastuti, T., Rizali, N. \& Yuliati, U. (2013). Empowerment of Lurik craftsmen through product diversification in order to maintain local culture. Surakarta: Cooperation between UNS and Ministry of Education and Culture of the Republic of Indonesia. Proceedings of the National Seminar.

Hitchcock, M. (1991). Indonesian textiles. Hong Kong: Periplus Editions Ltd. 